\title{
Identification of Anopheles Mosquito Species as Malaria Vector In Riau, Indonesia
}

\author{
Suri Dwi Lesmana ${ }^{1 *}$, Esy Maryanti ${ }^{1}$, Lilly Haslinda ${ }^{1}$, Wirjapratama Putra ${ }^{2}$, M. Noor Fadhillah ${ }^{2}$, \\ Fitra Rulian Anwar', Reza Lutfi ${ }^{2}$
}

\begin{abstract}
ABSTRAK
Malaria merupakan penyakit infeksi yang sering terjadi di negara tropis dan sub tropis, termasuk Indonesia. Provinsi Riau termasuk dalam kategori insidensi rendah dimana 58\% kabupaten telah menyandang status eliminasi malaria tahun 2016. Namun demikian daerah tersebut masih berpotensi menjadi daerah reseptif karena keberadaan vektor malaria yaitu nyamuk Anopheles yang terdiri dari beragam spesies. Penelitian ini bertujuan mengidentifikasi spesies nyamuk Anopheles dari 4 kabupaten di Provinsi Riau yaitu Kabupaten Indragiri Hilir, Rokan Hilir, Dumai dan Indragiri Hulu. Sampel diambil pada malam hari yang hinggap pada hewan maupun manusia yang dilanjutkan dengan identifikasi spesies secara morfologis. Observasi lingkungan dilakukan pada pagi hari. Terdapat tiga spesies Anopheles yang ditemukan yaitu dari sejumlah 219 ekor nyamuk terdapat 119 Anopheles sundaicus (54,34 \%), 99 Anopheles subpictus $(45,20 \%)$ and 1 Anopheles balabacensis (0,46 \%). Terdapat dua lokasi yang menjadi tempat perindukan utama yaitu rawa dan genangan air.
\end{abstract}

Kata Kunci : Nyamuk Anopheles, vektor malaria

Malaria is an infectious disease which often happens in tropical and sub tropical countries. ${ }^{1}$ Malaria is transmitted from the bite of Anopheles mosquito that contain Plasmodium as malaria parasite. There are 4 species of Plasmodium which can cause infections in humans consist of Plasmodium vivax (P.vivax), Plasmodium ovale (P.ovale), Plasmodium malariae (P. malariae) dan Plasmodium falciparum (P.falciparum). ${ }^{2}$

Malaria is one of the biggest parasitic problems in the world. Approximately 3.3 billion people worldwide and 1.2 billion people at high risk of malaria infection. Based on data from the WHO in 2014, Indonesia is one of the malaria endemic area with the number of cases as much as 343.527 cases and 45 deaths have been reported. ${ }^{3}$ According to the Health Department of Riau Province. In 2013, there are 19.756 cases of clinical malaria in Riau Province with Annual Malaria Incidence (AMI) 3.37

\footnotetext{
* Correspondent author: email: dr.soerie@gmail.com

1 Parasitology Department Medical Faculty , University of Riau, Pekanbaru, Riau, Indonesia

2 Student of Medical Faculty, University of Riau, Pekanbaru, Riau, Indonesia
}

and Annual Parasite Incidence (API) 0.24. Five districts with the highest AMI in Riau Province are Rokan Hilir District (15.57), Indragiri Hilir district (8.7), Pelalawan (7.1), Indragiri Hulu (3.65) dan Dumai City (1.91) and Indragiri Hulu (1.38). ${ }^{4}$ Based on Report in 2016 Riau is one of Province in Indonesia with low endemicity ( API $<1$ in 1000 people) and $58 \%$ area were successfully eliminated from malaria. ${ }^{5}$ However the area is still potential as a malaria receptive region because of malaria vector existance.

Malaria incidence is influenced by several factors, namely the host factors consist of humans, the vector (Anopheles mosquito), and the agent (Plasmodium spp). Riau Province environmental factors which is Topographically low-land, also has many small islands separated with the main-land by the sea, a lot of trenches, rivers, plantations, rice fields, forests; most of them are located close to the beach area and tropical climate region. ${ }^{6,7}$

Anopheles mosquito is the sole vector of malaria. ${ }^{8}$ Anopheles mosquito is one of the genus of the ordo Diptera, Famili Culicidae, and Subfamili Anophelinae. ${ }^{9}$ Anopheles mosquitoes are nocturnally 
active, its main activity in general between dusk and dawn. Anopheles mosquitoes live in lowland tropics and subtropics with high temperature and humidity. ${ }^{1,10}$

There are 430 species of Anopheles have been found worldwide and 25 species of them have been identified to have a role as the vector of malaria in Indonesia. ${ }^{11,12}$ The most common Anopheles mosquitoes species act as the vector of malaria in Indonesia are Anopheles sundaicus (An. sundaicus), Anopheles subpictus (An. subpictus), dan Anopheles balabacensis (An. balabacensis). ${ }^{3}$ There is a variety in the species of Anopheles mosquitoes in every region in Indonesia. Variation in number and also density is influenced by specific geographical conditions. ${ }^{13}$

There has been no up to date research on the bionomics of each species of Anopheles mosquitoes in the Province of Riau, recently. Study based on entomology survey required in order to determine the species of the Anopheles mosquitoes and its breeding sites which are useful for preventing and eradicating malaria in Riau Province appropriately. Based on this background, the researchers are interested in identifying of Anopheles mosquito species in Riau Province.

\section{METHOD}

This simple entomological survey based research was conducted in 4 Districts/City located in Riau Province that is Rokan Hilir District, Indragiri Hilir District, Dumai City and Indragiri Hulu. The tools needed in this research is aspirator, microscope, magnifying glass, object glass, cork, flashlight, tweezers, cotton, camphor, cover glass, mosquitoes pin, pipette, petri dish, camera, dipper and small bottle. ${ }^{14}$ The materials needed in this study is intact mosquitoes, $60 \mathrm{ml} / \mathrm{cc}$ of chloroform and a mosquitoes box. $^{14}$

The authors determine the location of the survey based on the information of the cluster of new Malaria cases that recently occurred in the region from local health department or community health centre/primary health care. Permission from local authorities was sought prior the study began.

\section{a. Breeding place observation}

Observation was done in 4 Districts located in Riau Province and to ensure the breeding places of Anopheles mosquito, the eggs and larvae were collected from suspected the breeding places (swamps, ditches, streams, ponds, and puddles). Furthermore, eggs and larvae were placed in the sample container and labeled. On the paper labels, note being made about information on the location of the sampling. Observation and larval catching conducted in the morning at around 08.00 o'clock.

\section{b. Mosquitoes collection}

Mosquitoes collection were done in 3 nights at each District / City from $07.00 \mathrm{pm}$ to $06.00 \mathrm{am}$. Collection was done in houses with cattle sheds around it. Mosquitoes were caught using an aspirator then they were inserted into a paper cup that had been covered with gauze. The mosquitoes were captured while they were in the resting state on a plant, the walls on the house, and or in the state of it were sucking cattle's blood. Some mosquitoes also caught by human landing method.

\section{c. Mosquitoes Identification}

Identification was done firstly with separation between Anophelini Tribe and Culicini Tribe and then followed by the identification of the Anopheles mosquito species. Identification of the Anopheles mosquitoes macroscopically and microscopically was done at the Laboratory of Parasitology, Faculty of Medicine Riau University using Anopheles mosquito identification keys. ${ }^{15}$

\section{RESULT}

Based on the result of mosquito identification in Riau Province there are total 2252 mosquitoes caught in 4 Districts. The number of isolated from Rokan Hilir Districts as much as 554 mosquitoes, Indragiri Hilir Districts as much as 627 mosquitoes and Dumai City as much as 589 mosquitoes and Indragiri Hulu as much as 489 mosquitoes. The whole mosquitoes identified consist of Anophelini Tribe and Culicini Tribe. Mosquitoes collection were done at night in the cattle sheds around houses and 
by human landing method also.

Identification was done firstly with separation between Anophelini Tribe and Culicini Tribe. Culicini Tribe was not further identified to each genus in this research. There are distinctive morphological differences between Anophelini Tribe (Figure 1a) and Culicini Tribe (Figure 1b) in their palps and proboscis. Like all mosquitoes, adult Anopheles species have slender bodies with three sections: head, thorax and abdomen. Anopheles mosquitoes can be distinguished from other mosquitoes by the palps, which are as long as the proboscis, and by the presence of discrete blocks of black and white scales on the wings. Adults can also be identified by their typical resting position: males and females rest with their abdomens sticking up in the air rather than parallel to the surface on which they are resting. ${ }^{16}$

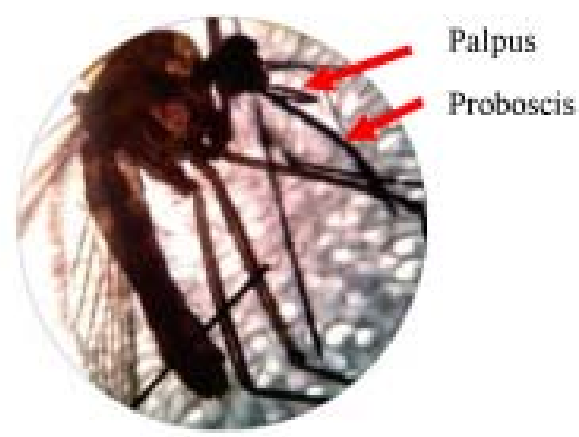

Figure 1b. Culicini Tribe

(40x magnification using light microscope)

Figure 1a. Anophelini Tribe

(40x magnification using light microscope)

Mosquitoes Tribe in Riau Province which have been collected and identified in 4 Districts/ City can be seen in Table 1.

Table 1 Mosquitoes Tribe isolated in Riau Province,2020

\begin{tabular}{llllll}
\hline \multirow{2}{*}{ Tribus } & \multicolumn{4}{c}{ Districts / City } & \multirow{2}{*}{ Total (\%) } \\
\cline { 2 - 5 } & Rokan Hilir & Indragiri Hilir & Dumai & Indragiri Hulu & \multirow{2}{*}{ ( $19(9.72)$} \\
\hline Anophelini & $57(2.53)$ & $57(2.53)$ & $62(2.75)$ & $43(1.9)$ & \\
Culicini & $497(22.07)$ & $570(25.31)$ & $527(23.40)$ & $439(19.50)$ & $2033(90.28)$ \\
\hline Total & $554(24.60)$ & $627(27.84)$ & $589(26.15)$ & $482(21.40)$ & $2252(100)$ \\
\hline
\end{tabular}

According to table 1, mosquitoes tribe in Riau Province which have been collected and identified in 4 Districts / City amount to as much as 2252 mosquitoes totally. Anophelini Tribe as much as 219 mosquitoes (9.72 \%) and Culicini Tribe as much as 2033 mosquitoes (90.28\%).

\section{Anopheles Mosquitoes Species in Riau Province}

After separating Anophelini Tribe and Culicini Tribe, then the next step is identifying the species of Anopheles mosquitoes. Anopheles mosquitoes species which have been identified in Riau Province can be seen in table 2. Identification of anopheles species can be seen from the shape of the palpus, wing, femur and tibia 
Table 2. Anopheles Mosquitoes Species in Riau Province

\begin{tabular}{|c|c|c|c|c|c|}
\hline \multirow[b]{2}{*}{$\begin{array}{l}\text { Anopheles mosquitoes } \\
\text { species }\end{array}$} & \multirow[b]{2}{*}{ Rokan Hilir } & \multicolumn{2}{|c|}{ Districts / City } & \multirow[b]{2}{*}{$\begin{array}{c}\text { Indragiri } \\
\text { Hulu }\end{array}$} & \multirow[b]{2}{*}{ Total $(\%)$} \\
\hline & & $\begin{array}{l}\text { Indragiri } \\
\text { Hilir }\end{array}$ & Dumai & & \\
\hline Anopheles sundaicus & $47(21.46)$ & $22(10.04)$ & $50(22.83)$ & $43(19.63)$ & $162(73.97)$ \\
\hline Anopheles subpictus & $10(4.57)$ & $34(15.53)$ & $12(5.48)$ & $0(0)$ & $56(25.57)$ \\
\hline $\begin{array}{l}\text { Anopheles } \\
\text { balabacensis }\end{array}$ & $0(0)$ & $1(0.46)$ & $0(0)$ & $0(0)$ & $1(0.46)$ \\
\hline Total & 57 & 57 & 62 & 43 & $219(100)$ \\
\hline
\end{tabular}

According to table 2, the species of Anopheles mosquitoes in Riau Province which have been identified amount to as much as 219 mosquitoes. Consist of 162 An. sundaicus mosquitoes (73.97 \%), 56 An. subpictus mosquitoes (25.57\%) and 1 An. balabacensis mosquitoes (0.46\%).

All 3 species are distinguished by Anopheles mosquitoes key identification. An. sundaicus (Figure

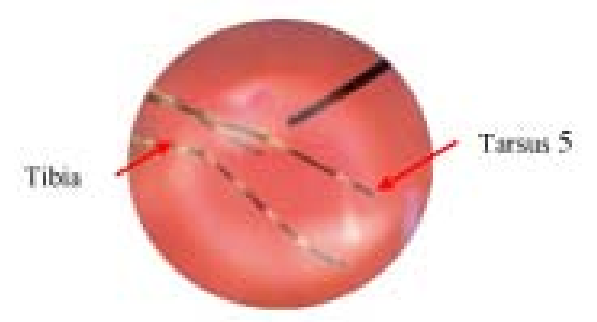

Figure 2a.Ar. sunhinicws (40x magnification using light mikroskop) 2a and figure 2b) has speckled femur and tibia, no broad white band at the tibia-tarsal joint, and dark tarsus 5. An. subpictus (Figure 3a and figure 3b) has no speckled femur and tibia, no broad white band at the tibia-tarsal joint and dark tarsus 5. An. balabacensis (Figure 4) with speckled femur and tibia, with broad white band at the tibia-tarsal joint and many dark segment on the sixth vein of the wings. 15.17

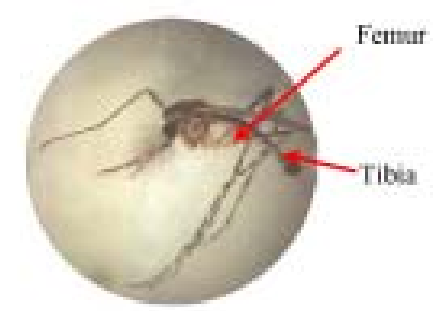

Gambar 2b.An swmoloicus (2x magnification using insects mïcroecope)

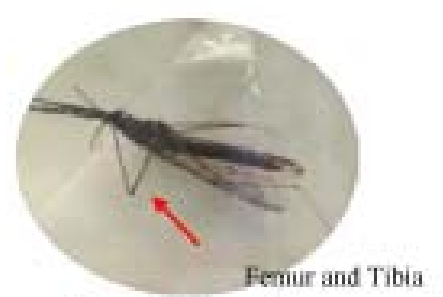

Figure ia. An. sahnicrus ( $2 x$ magnification using insects microscope)

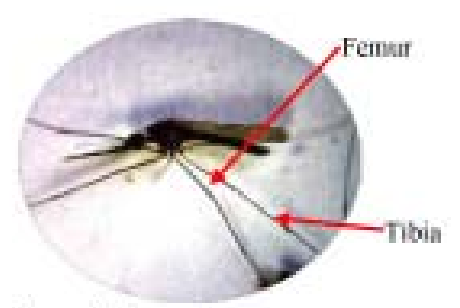

Finure $3 \mathrm{~b} \cdot 4 n$ smbovicus (2x magnification using insccts microscope)

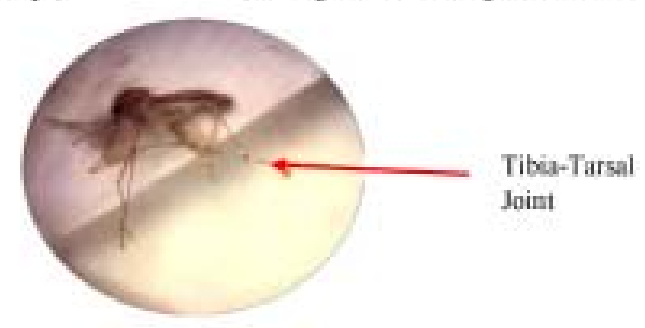

Figure $4 \cdot f u$ Bubhacewus

(2x magnification using inscets mictoscope) 
The Overview of Environment as The Breeding Places Of Anopheles Mosquitoes

The overview of environment as the breeding places of Anopheles mosquitoes was done with observations on the morning that aims to determine the Anopheles mosquitoes breeding places. Followed by Anopheles larvae detention with 2 different sampling locations for each location: swamps, ditches, rivers, ponds, puddles which aims to verify whether the sites were the_breeding places of Anopheles mosquitoes. Observation and detention carried out in 4 Districts / City: Rokan Hilir District, Indragiri Hilir District and Dumai City. The overview of environment as the breeding places of Anopheles mosquitoes can be seen in table 3 .

Table 3 The Overview of Environment as the Breeding Places of Anopheles Mosquitoes

\begin{tabular}{llll}
\hline \multirow{2}{*}{ Breeding Places } & \multicolumn{3}{c}{ Districts / City } \\
\cline { 2 - 4 } & Rokan Hilir & Indragiri Hilir & Dumai \\
\hline Swamp 1 & Negative & Negative & Negative \\
Swamp 2 & Positive & Negative & Negative \\
Ditch 1 & Negative & Negative & Negative \\
Ditch 2 & Negative & Negative & Negative \\
River 1 & Negative & Negative & Negative \\
River 2 & Negative & Negative & Negative \\
Pond 1 & Negative & Negative & Negative \\
Pond 2 & Negative & Negative & Negative \\
Puddle 1 & Negative & Positive & Positive \\
Puddle 2 & Negative & Positive & Negative \\
\hline
\end{tabular}

According to table 3 , from 30 breeding places, there were 4 location that was at swamp 2 in Rokan Hilir and Rokan Hulu District, Puddle 1 and 2 in Indragiri Hilir District and Puddle 1 in Dumai City with positive Anopheles larvae.

\section{DISCUSSION}

This research was a descriptive study including collection and identification of Anopheles mosquitoes species in Riau Province and the overview of the environment as the breeding places of Anopheles mosquitoes. Based on the results of identification, there were 2252 mosquitoes consists of Anophelini Tribe and Culicini Tribe.

(9.72\%) and 2033 Culicini Tribe Mosquitoes (90.28\%) which means that Culicini Tribe was more dominant compared to Anophelini tribe. Culicini Tribe consists of Aedes, Culex, Mansonia and others. ${ }^{17}$ Collection was done at night, so the mosquitoes caught were night-bitter mosquitoes. Night-bitter mosquitoes are Anopheles, Culex, and Mansonia. ${ }^{19,20}$
This result was similar with some previous researches. According to Rosa et al ${ }^{20}$ study in Lampung in 2009 stated that Culicini Tribe was the most dominating Tribe in the amount of $88.37 \%$ and 92.21\% both in the home and outside the home and followed by Anophelini Tribe 11.64\% in the home and $7.79 \%$ outside the home. The study result conducted by Taviv at Village II Nipah Panjang and Teluk rendak Jambi also stated that Culicini Tribe was the most dominating compared to Anophelini Tribe. ${ }^{21}$ This result was due to Culicini Tribe population is larger than Anophelini tribe and there are many breeding places that support the Culicini Tribe. For example, Culex mosquitoes can breed in any puddles that are directly related to ground. ${ }^{21}$

The species of Anopheles mosquitoes in Riau Province which have been identified amount to as much as 219 mosquitoes overall. They consisted of 162 An. sundaicus mosquitoes (73.97 \%), 56 An. subpictus mosquitoes (25.57 \%) and $1 \mathrm{An}$. balabacensis mosquitoes (0.46 \%).

All 3 species are distinguished by Anopheles mosquitoes key identification. An. sundaicus has speckled femur and tibia, no broad white band at 
the tibia-tarsal joint, hind tarsus 5 all dark and two dark segments on the sixth vein of the wings. An. subpictus has no speckled femur and tibia, no broad white band at the tibia-tarsal joint and hind tarsus 5 all dark. An. balabacensis has speckled femur and tibia, with broad white band at the tibia-tarsal joint and many dark segments on the sixth vein of the wings. ${ }^{17}$

This result was similar with some previous researches. Kazwaini study at Hadakamali Village East Nusa Tenggara stated that the most Anopheles mosquitoes species found was An. sundaicus and An. subpictus. An. sundaicus was the most dominating species $(92.84 \%){ }^{23}$ Shinta study in Banyuwangi beach West Java also stated that $A n$. sundaicus (67.86 \%) was the most dominating species. ${ }^{24}$ Rosa in Lampung in 2009 also stated that An. sundaicus was the most dominating species as much as $58.87 \%{ }^{21}$

Based on the result of this study and previous study, it could be seen that An. sundaicus was the most dominating species. Based on theory, there are 4 different location as the breeding places of Anopheles. There are coastal areas, inland areas, the foot of the mountain and mountain. The coastal area which consists of swamp, pond, lagoon and mangrove plants are the breeding places of $A n$. sundaicus and An. subpictus. Inland area which consists of rice fields, swamps, ponds, and irrigation channels are the breeding places of An. subpictus, An. aconitus, An. barbirostris, An. nigerrimus and An. sinensis. The foot of a mountain which consists of plantations and forests are the breeding places of Anopheles balabacencis and mountain is the breeding place of Anopheles maculatus. ${ }^{9}$

Topographic of Riau Province is generally lowland, a lot of small islands, and a tropical climate which are match with the breeding places of Anopheles mosquitoes. Topographic of the study area is an area with a lot of trenches, rivers, plantations, rice fields, woods, and close to the beach area which are the breeding places of An. sundaicus, An. subpictus and An. balabacensis5 ${ }^{10}$ This is the reason why there are An. sundaicus, An. subpictus and An. balabacensis found in Riau Province.

Bionomics of Anopheles sundaicus are nightbitter mosquitoes, exophagy, exophily and zoophily, has a long flying distances, ranging from 1,9-6 km dan the longevity reanged from 8-9 days. ${ }^{25.26}$ Biting activity of An. sundaicus reached its peak at 20.0021.00 o'clock dan 22.00-01.00 o'clock inside the house, at 23:00-24:00 o'clock and 03.00-05.00 o'clock outside the house. ${ }^{26}$ Bionomics of An. subpictus are night bitter-mosquitoes, eksophily, zoophily, exophagy>endophagy, flying distances ranged from 1,5-6 km dan the longevity ranged from $2-21$ days and $>50 \%$ of them have the longevity more than 7 days. ${ }^{28,29}$ Biting activity of $A n$. sundaicus reached its peak at 22.00-23.00 o'clock dan 02.00-03.00 o'clock inside the house, at 19:0020:00 o'clock, 23.00-01.00 o'clock and 03.00-05.00 o'clock outside the house. ${ }^{27}$ Bionomics of Anopheles balabacensis are night-bitter mosquitoes endophily and zoophily. ${ }^{30}$ Anopheles balabacensis is active in the second quarter of the night until the morning. ${ }^{31}$

Collection was done at 19.00-06.00 in the outdoors, especially around the cattle sheds and $A n$. sundaicus, An. subpictus dan An. balabacensis were found in this study. Based on theory and previous research, bionomics of both species matched to the location and time of collection. It is very important to know the behavior and habitat of each species of Anopheles mosquitoes that are beneficial for the eradication and prevention of malaria cases in Riau Province as a malaria endemic area.

The overview of environment as the breeding places of Anopheles mosquitoes was done with observations on the morning that aims to determine the Anopheles mosquitoes breeding places. Followed by Anopheles larvae detention with 2 different sampling locations for each location : swamps, ditches, rivers, ponds, puddles which aims to verify whether the sites were the_breeding places of Anopheles mosquitoes. Observation and detention carried out in 3 Districts / City: Rokan Hilir District, Indragiri Hilir District and Dumai City. The results from 30 locations showed that there were 4 positive locations for Anopheles larvae, two swamps in Rokan Hilir District, Puddle 1 and 2 in Indragiri Hilir District and Puddle in Dumai City.

The sampling sites were adapted to the breeding places of Anopheles mosquitoes existing in theory and previous study. Swamps, ditches, rivers, ponds, puddles are directly related to ground which is the breeding places of Anopheles mosquitoes, 
according to Bustam study which stated that the breeding places of Anopheles mosquitoes are murky water and clear water that is directly related to the ground. ${ }^{32}$ Kazwaini dan Boewono study also stated that Anopheles mosquitoes like ground related puddle, murky water, clear water, brackish water in estuaries, swamps with no relation to the sea, sewers, flowing water and stagnant water condition and sunlight exposure or no sunlight exposure. ${ }^{9,32-34}$

This result was similar with some previous researches. -The study conducted by sariin 2007 at Rukoh Village Syiah Kuala District Banda Aceh City stated that the breeding places of Anopheles mosquitoes are swamps. ${ }^{35}$ Shinta study at Batam in 2010 stated that the breeding places of Anopheles mosquitoes are swamps, puddles, ditches, and others. ${ }^{36}$ Nurhayati also stated that there are 6 kinds of Anopheles mosquitoes breeding places include swamps, puddles, water containers, sink leg, cattle drinking containers and ditches. ${ }^{37}$ Topographic of Riau Province consist of swamps, ditches, rivers and puddles which were the location expected to be the breeding places of Anopheles mosquitoes.

In this study, swamps and puddles are the location with calm water while the ditches and rivers are the location with flowing water. Based on theory and previous research, many factors can affect the breeding places of Anopheles mosquitoes. One of the factors that can influence the breeding places of Anopheles mosquitoes is physical factor that is rain. This study was conducted in December, which is in rainy season. More heavy rain, the water level and water flow will become swifter primarily on the location of rivers and streams. Heavy water flow will eliminate the larvae because its carried away by the water flow. ${ }^{38}$ Ernamaiyanti study stated that Anopheles mosquitoes preferstagnant water to breed, e.g in swamps and quiet ditches. Beside rain factor, sunlight is also very affecting the existence of Anopheles larvae. Each species of Anopheles mosquitoes have the most favored places to breed that are directy exposed to sunlight or indirectly exposed. Sunlight is a natural energy that affects the humidity and temperature. Humidity and temperature also affect the existence of Anopheles larvae. ${ }^{39}$ The results of this study found Anopheles larvae at puddles around the cattle sheds. Muchid study in Middle Sulawesi also stated that puddles around the cattle sheds were the breeding places of Anopheles mosquitoes. ${ }^{40}$

It is important to know the exact breeding places of Anopheles mosquitoes in order to control the Anopheles mosquitoes as the malaria vector. Some efforts on vector control can be done, e.g larviciding (control of the Anopheles larvae chemically using insecticide), biological control (using larvae-eating fish), environmental management and the others. ${ }^{41}$

The efforts of vector control on the three species found in this study that is draining the flooded swamps, draining the stagnant water in the mangrove plants, cleaning the estuaries and setting the salinity in the area. ${ }^{42}$ The breeding places of Anopheles mosquitoes can be affected by many factors, such as physical factors, biological factors and sociocultural factors. Therefore, furtherstudy onthe factors that may affect the Anopheles mosquitoes breeding places as the vector of malaria needed to be conducted.

\section{CONCLUSION}

From this descriptive research, identification of the Anopheles mosquitoes species in Riau Province as a malaria hipoendemic area can be concluded that Anopheles mosquitoes species found in Riau Province were Anopheles sundaicus, Anopheles subpictus and Anopheles balabacensis. Breeding Places of Anopheles mosquitoes in Riau Province were swamp and puddles.

\section{REFERENCES}

1. Centre of Disease Control and Prevention. Where malaria occurs. [cited 2015 April 10]. Available from: http://www.cdc.gov/malaria/ about/distribution.html

2. White NJ, Breman JG. Penyakit malaria dan babesiosis. In: Asdie, A.H editor . Harrison prinsip-prinsip Ilmu Penyakit Dalam. 13rd ed. Jakarta: EGC; 2000. P.1001-1002.

3. World Health Organization. World malaria report 2014. Geneva. WHO/UNICEF; 2014.

4. Dinas Kesehatan Provinsi Riau. Profil kesehatan Provinsi Riau tahun 2013. Pekanbaru:Dinas 
Kesehatan Provinsi Riau;2013

5. Kementerian Kesehatan Republik Indonesia. Eliminasi malaria Indonesia[internet]. Available from: http://www.malaria.id/

6. Departemen Kehutanan. 33 provinsi profil kehutanan. Available from: http:// www.dephut.go.id/uploads/files/ 76333af5b0c4474a6498f7d3d1303470.pdf.

7. Arsin AA. Malaria di Indonesia tinjauan aspek epidemiologi. Makassar: Masagena Press; 2012. P. $85-100$

8. Mosquito Taxonomic Inventory. Genus Anopheles Meigen, 1818. [Cited 2015 Mei 10]. Available from: http://mosquito-taxonomic-inventory.info/ genus-anopheles-meigen-1818

9. Natadisastra D, Agoes R. Parasitologi kedokteran ditinjau dari organ tubuh yang diserang. Penerbit buku kedokteran EGC. Penyakit sporozoa darah dan jaringan. $1^{\text {st }}$ ed. Jakarta.

10. Harijanto PN. Epidemiologi Malaria. Malaria, Epidemiologi, Patogenesis, Manifestasi Klinis dan Penanganan. Jakarta: EGC; 2000.

11. Centre of Disease Control and Prevention. Anopheles Mosquitoes. [Cited 2015 April 10]. Available from: http://www.cdc.gov/malaria/ about/biology/mosquitoes/

12.Laihad FJ, Harijanto PN, Poesprodjo JR. Epidemiologi Malaria di Indonesia. Kementrian Kesehatan RI; 2011.

13. Sinka Me, Bangs MJ, Manguin S, Rubio-Palis Y, Chareonviriyaphap T, Coetzee M, et al.A global map of dominant malaria vectors. Parasit vectors 2012, 5:69.

14. Wardhani K, Eskarindini VE, Muliantari NK, Teba YR, Satyani HA, Rahda NK, et al. Laporan praktikum pengendalian vektor identifikasi larva dan nyamuk aedes, anopheles dan culex.Universitas Udayana; 2010.

15. Reid JA. Anopheline Mosquitoes of Malaya and Borneo. Government of Malaysia; 1968.

16. Haslinda L, Yolazenia, Maryanti E, Lesmana SD. Buku penuntun praktikum parasitologi edisi 5. Pekanbaru : Fakultas Kedokteran Universitas Riau. 2013.
17.Departemen Parasitologi FKUI. Penuntun praktikum entomologi. Jakarta: Universitas Indonesia p.96-102.

18. University of Wyoming. Mosquitoes. Available from: [http://www.uwyo.edu/vetsci/ undergraduates/courses/patb_4360/ mosquitoes.ppt].

19. Tiawsirisup S, Nithiuthai S. Vector competence of Aedes aegyppti(1.) and Culex quinquefasciatus (say) for Dirofilaria imitis (leidy). 2006. Available from: http:// tm.mahidol.ac.th

20.Kurniati A. Efektifitas fermentasi gula sebagai atraktan nyamuk[skripsi]. Medan: Universitas Sumatra Utara. 2015.

21. Rosa E, Setyaningrum E, Murwani S, Halim I. Identifikasi dan aktivitas mengigit nyamuk vektor malaria di Daerah Pantai Puri Gading Kelurahan Sukamaju Kecamatan Teluk Betung Barat Bandar Lampung. Lampung: Universitas Lampung; 2009.

22. Taviv Y, Budiyanto A, Sitorus H, Ambarita LP, Mayasari R, Pahlepi RI. Sebaran nyamuk Anopheles pada topografi wilayah yang berbeda di Provinsi Jambi. Media Litbangkes Kementerian Kesehatan Republik Indonesia. 2015. 25(2):3.

23.Kazwaini M, Willa RW. Korelasi kepadatan Anopheles spp. Dengan curah hujan serta status vektor malaria pada berbagai tipe geografi di Kabupaten Sumba Timur Provinsi Nusa Tenggara Timur. Buletin Penelitian Kesehatan. 2015. 43 (2):81.

24. Shinta, Sukowati S, Mardiana. Komposisi spesies dan dominasi nyamuk Anopheles di daerah pantai banyuwangi jawa timur. Media Litbang Kesehatan.2003. 13(3).

25.Dusfour I, Harbach RE, Manguin S. Bionomics and systematics of the riental Anopheles sundaicus complex in relation to malaria transmission and vector control. The American Journal of Tropical Medicine and Hygiene. 2004.

26. Susanna D, Eryando T. The longevity of Anopheles sundaicus in a small area: Nongsa Pantai Villages, Batam City, Indonesia. Malaria Journal 2012; 11(Suppl 1): P93. 
27. Adrial, Harminarti N. Fluktuasi padat populasi Anopheles subpictus dan Anopheles sundaicus di daerah endemik Kenagarian Sungai Pinang Kecamatan Koto XI Tarusan, Kabupaten Pesisir Selatan. Padang : Universitas andalas. 2010.

28. Elyazar I, Hay S, Baird JK. Malaria Distribution, Prevalence, Drug Resistance and Control in Indonesia. Adv Parasitol. 2011; 74: 41-175.

29. Singh KR, Kumar G, Mittal PK, Dhiman RC. Bionomics and vector potential of Anopheles subpictus as a malaria vector in India : an overview. IJMR 2014; 1(1):29-37.

30. Sutanto I, Ismid IS, Sjarifuddin PK, Sungkar S. Parasitologi kedokteran. Jakarta: Badan Penerbit Fakultas Kedokteran Universitas Indonesia; 2008;254-7

31.Kirnowardoyo S. Anopheles balabacensis baisas 1936 di Kalimantan Timur. Jakarta: Seminar entomologi kesehatan. 1985

32. Bustam, Ruslan, Erniwati. Karakteristik tempat perkembangkbiakan larva Anopheles di Desa Bulubete Kecamatan Dolo Selatan Kabupaten Sigi Provinsi Sulawesi Tengah. Makassar: Universitas Hasanuddin. 2012.

33.Kazwaini M, Martini S. Tempat Perindukan vektor, spesies nyamuk Anopheles, dan pengaruh jarak tempat perindukan vektor nyamuk Anopheles terhadap kejadian malaria pada balita. Jurnal Kesehatan Lingkungan 2006; 2(2) P 173182.

34. Boewono DT. Studi bioekologi vektor malaria di Kecamatan Srumbung Kabupaten Magelang Jawa Tengah. Simposium nasional hasil-hasil litbangkes 2004. [Cited 2015 Desember 28]. Available from: http://www.litbang.depkes.go.id/ $\sim$ djunaedi/data/Damar.pdf

35. Sari W, Zanaria TM, Agustina E. Studi jenis nyamuk Anopheles pada tempat peindukannya di Desa Rukoh Kecamatan Syiah Kuala Kota Banda Aceh. Banda Aceh: Universitas Syiah Kuala.

36. Shinta, Sukowati S, Mardiana. Bionomik vektor malaria nyamuk Anopheles sundaicus dan Anopheles letifer di kecamatan belakang padang, batam, kepulauan riau. Buletin Penelitian Kesehatan 2011. Available at: http:// ejournal.litbang.depkes.go.id/index.php/BPK/ article/view/2704/618 [diakses tanggal 26 Januari 2016]

37. Nurhayati HL, Ishak H, Anwar. Karakteristik tempat perkembangbiakan Anopheles sp. di wilayah kerja Puskesmas Bonto Bahari Kabupaten Bulukumba. Fakultas Kesehatan Masyarakat Universitas Hasanuddin. 2014. p.4.

38.Pratama GY. Nyamuk Anopheles sp dan faktor yang mempengaruhi di kecamatan rajabasa, lampung selatan. Lampung : Fakultas Kedokteran Universitas Lampung. 2015.

39.Ernamaiyanti, Kasry A, Abidin Z. Faktor-faktor ekologis habitat larva nyamuk Anopheles di desa muara kelantan kecamatan sungai mandau kabupaten siak provinsi riau tahun 2009. Riau : Universitas Riau. 2010.

40.Muchid Z, Annawaty, Fahri. Studi keanekaragaman nyamuk Anopheles spp. Pada kandang ternak sapi di Kota Palu Provinsi Sulawesi Tengah. Online Jurnal of Natural Science. 2015. 4(3):374.

41.Laihad FJ, Harijanto PN, Poesprodjo JR. Epidemiologi Malaria di Indonesia. Kementrian Kesehatan RI; 2011.

42.Nurmaini. Mentifikasi vektor dan pengendalian nyamuk Anopheles aconitus secara sederhana. Medan : Fakultas Kesehatan Masyarakat Universitas Sumatera Utara. 2003. 